\title{
A seed morphometry study of selected species of Bulbophyllum and Dendrobium (Orchidaceae) in relation to their dispersals
}

\author{
POPI APRILIANTI", ELIZABETH HANDINI, DWI MURTI PUSPITANINGTYAS \\ Research Center for Plant Conservation and Botanic Gardens, National Research and Innovation Agency. J1. Ir. H. Juanda No. 13, Bogor 16122, West \\ Java, Indonesia. Tel./fax.: +62-271-663375, `email: poppy.amb@gmail.com \\ Manuscript received: 27 July 2021. Revision accepted: 27 November 2021.
}

\begin{abstract}
Aprilianti P, Handini E, Puspitaningtyas DM. 2021. A seed morphometry study of selected species of Bulbophyllum and Dendrobium (Orchidaceae) in relation to their dispersals. Biodiversitas 22: 5564-5571. Bulbophyllum and Dendrobium are the two largest genera of Orchidaceae. The seed morphometry studies of Bulbophyllum and Dendrobium, mainly from Southeast Asia are still poorly reported. The research aimed to characterize seeds micromorphometry of selected species of Bulbophyllum and Dendrobium, namely Bulbophyllum graveolens, B. macranthum, B. phalaenopsis, Dendrobium bicaudatum, and D. bifalce in relation to their dispersal mechanisms. Twenty seeds of each species were studied using light and scanning electron microscope (SEM). Qualitative characters, such as seed shape, testa cell shape, wall structure, and its orientation and quantitative data, such as seed and embryo were analyzed. The results showed that the shape of the seeds of all the species was fusiform. The testa cell walls were smooth and covered by waxes. The anticlinal walls were raised and thickened. Bulbophyllum and Dendrobium can be differentiated in the orientation of testa cells, which is spirally oriented in Bulbophyllum and parallel to the long axis in the Dendrobium. There are no large variations in seed and embryo volume as well as seed air space (SAS) in different taxa. The SAS value can be used to predict the dispersal mechanism and distribution area of the orchid species. Unfortunately, the SAS values are not always positively correlated with the distribution area and other factors inhibit the spread of the species.
\end{abstract}

Keywords: Bulbophyllum, Dendrobium, distribution area, morphometry, orchid seed air space

Abbreviations: SAS: Seed air space, SEM: Scanning electron microscope

\section{INTRODUCTION}

Orchidaceae consists of 22.000 species in 880 genera (Barthlott et al. 2014). Orchid seeds are unique and vary in shape, color, size, embryo volume, and the structure of testa cells. Single fruit has numerous, light, and tiny seeds compared with other flowering plants (Ramudu and Khasim 2015). This large number of seeds have very specific germination requirements, such as mycotrophy (Arditti and Ghani 2000). These dust seeds are dispersed by the wind over a long-distance and exhibit broad morphological characters (Chaudhary et al. 2014; Ramudu et al. 2020).

The common shape of the orchid seed is fusiform and the color is whitish, brownish, greenish, yellowish, or black with the size ranging from $100 \mu \mathrm{m}$ (Oberonia similis (Blume) Lindl.) to $6000 \mu \mathrm{m}$ (Epidendrum secundum Jacq.) (Barthlott et al. 2014). Embryo volume varies between c. $0.0001 \mathrm{~mm}^{3} \times 1000^{3}$ to $5.0 \mathrm{~mm}^{3} \times 1000^{3}$ (Arditti and Ghani 2000). The testa wall that covers the embryo was smooth or reticulated with the secondary wall thickenings on periclinal and anticlinal cell walls as the most prominent pattern is (Swamy et al. 2004; Barthlott et al. 2014). There is also air space surrounding the embryo with various values based on the species (Yeung 2017; Diantina et al. 2020).

Scanning electron microscope (SEM) is commonly used to analyze the microstructures of orchid seeds. The previous studies on microstructures have been conducted on some Turkish orchids (Güler 2016; Şeker et al. 2021), Phalaenopsis, Paphiopedilum, and Dendrobium native to Indonesia (Hariyanto 2019; Hariyanto et al. 2020), tropical and temperate orchid (Diantina et al. 2020), Western Himalayan orchids (Verma et al. 2014), Gulf of Guinean orchids (Gamarra et al. 2018), orchids of Manipur (Tongbram et al. 2012), Paphiopedilum and Cypripedium native to China (Zhang et al. 2015). These studies exhibit more understanding of the differences between species of orchid seed. Seed morphometry and morphology have given contributions to taxonomic, phylogenetic, and phytogeographic studies on orchids (Arditti and Ghani 2000; Barthlott et al. 2014; Koene et al. 2020). Seed morphology provides relevant information about evolution, ecological processes like dormancy, germination, and the dispersal adaptation of the orchid species to the specific habitat (Arditti and Ghani 2000; Gammara et al 2018). It is also important to understand the reproduction biology process of the orchid species, which can be applied for its conservation and propagation study, including seed storage (Diantina et al. 2020).

Orchid significance as the ornamental plants made them overexploited. The loss and destruction of their habitat are getting severe due to human activities and the effect of climate change (Barman and Devadas 2013; Zhang et al. 2015). Bulbophyllum and Dendrobium are the two largest 
genera of Orchidaceae. Bulbophyllum consists of more than 2200 that are distributed widely in tropical and subtropical regions and Asia was considered as the major diversity center of Bulbophyllum (Comber 2001; Vermeulen et al. 2015). Dendrobium is also diverse genera with approximately 1580 species (Wood 2013).

The studies of seed micromorphometry of Bulbophyllum and Dendrobium species from Southeast Asia are still poorly reported. More studies are needed to learn about their dispersal mechanisms compared with seed characters. So far, there have been approximately eight species of Bulbophyllum (Arditti and Ghani 2000; Swamy et al. 2004) and 20 species of Dendrobium in the tropical zone ( $\pm 20 \%$ of Dendrobium in Asia mainland) (Arditti and Ghani 2000; Chaudhary 2014; Diantina et al. 2020; Hariyanto et al. 2020) from Asia that have been studied for their seed micromorphometry. The present study was conducted on Bulbophyllum and Dendrobium which were collected in Bogor Botanic Gardens. This study aimed to characterize the seeds' micromorphometry of the selected species of Bulbophyllum and Dendrobium in relation to their dispersal mechanisms.

\section{MATERIALS AND METHODS}

\section{Plant materials}

The research was conducted from January to April 2021. Seeds of five orchid species of Bogor Botanic Gardens' Indonesia collections were harvested from mature and naturally dehiscing capsules. For obtaining the fruits, the flowers were hand-pollinated in the Orchid Glass House. There were three species of Bulbophyllum, namely B. graveolens (F.M. Bailey) J. J. Sm., B. macranthum Lindl., and B. phalaenopsis J. J. Sm. and two species of
Dendrobium, namely D. bicaudatum Reinw. ex Lindl. and D. bifalce Lindl. (Figure 1). The mature seeds were released from the capsule and dried for 7 days in the desiccator.

\section{Observation of seed micromorphology}

Seed samples were sterilized with $5 \%$ chlorox solution for 5 minutes and rinsed with sterile distilled water. Twenty seed samples were then observed and photographed under Light Microscope (LM) Olympus U-TV0.5XC-3 with a magnification 10 or 40 times. The morphological parameters used LM, including seed shape (SS), seed length (SL), seed width (SW), seed length/seed width (SL/SW), and seed volume (SV). For embryos, we also measured embryo length (EL), embryo width (EW), embryo length/embryo width (EL/EW), and embryo volume $(\mathrm{EV})$.

\section{Data analysis}

Seed Volume (SV), Embryo Volume (EV), and Seed Air Space (SAS) were calculated with the formula:

$$
\begin{aligned}
& \mathrm{SV}=2\left[(\mathrm{SL} / 2)(\mathrm{SW} / 2)^{2}(\pi / 3)\right] \\
& \mathrm{EV}=4 / 3 \pi(\mathrm{EL} / 2)(\mathrm{EW} / 2)^{2} \\
& \mathrm{SAS}=((\mathrm{SV}-\mathrm{EV}) / \mathrm{SV}) \times 100 \% \\
& \text { (Arditti and Ghani 2000). }
\end{aligned}
$$

The qualitative parameters were observed with Scanning Electron Microscope (SEM), such as seed shape, anticlinal and periclinal wall structure, cell shape in chalazal, micropylar, and median region (Şeker et al. 2021). The seed samples were sputter-coated with gold and observed with SEM JSM-IT 200. The terminology of qualitative and quantitative characters was based on Arditti and Ghani (2000) and Barthlott et al. (2014).

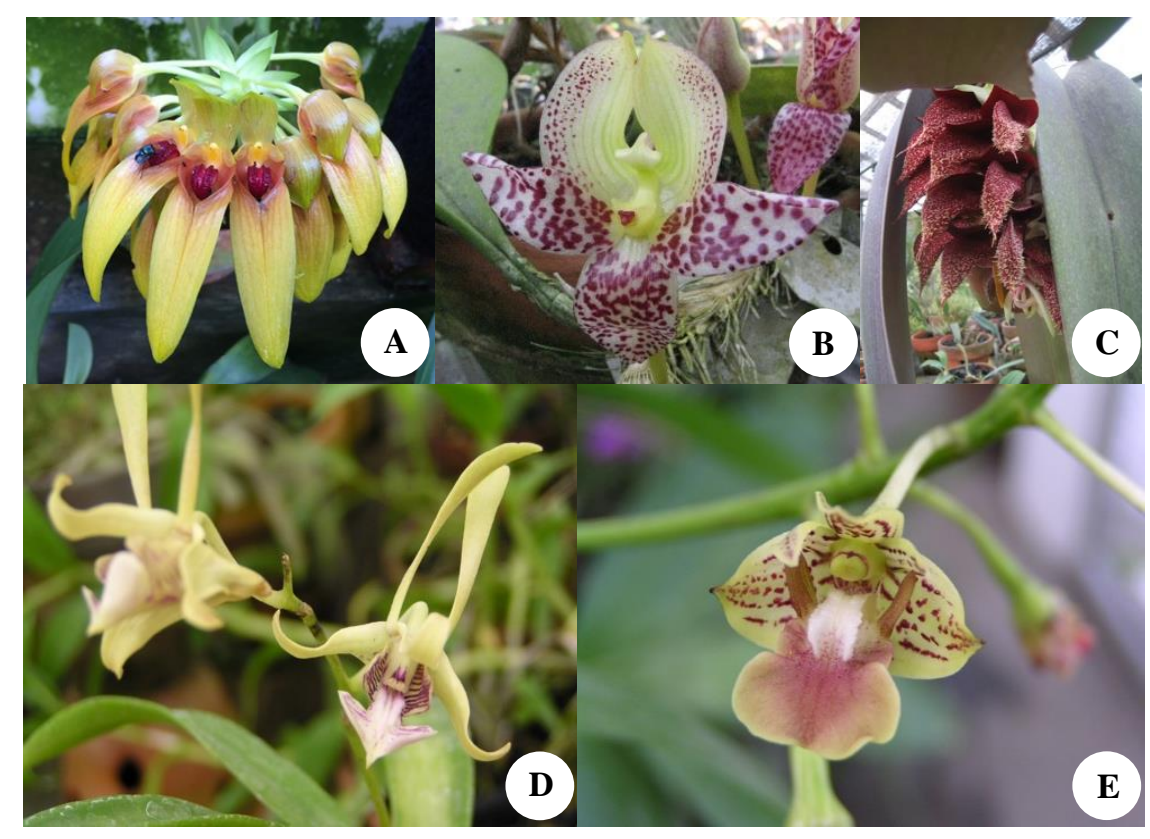

Figure 1. Orchid species were used in the study. A. Bulbophyllum graveolens, B. B. macranthum, C. B. phalaenopsis, D. Dendrobium bicaudatum, E. D. bifalce 


\section{RESULTS AND DISCUSSION}

\section{Morphological character of seeds}

Bulbophyllum and Dendrobium are the genera that are included in subfamily Epidendroideae subtribe Dendrobiinae (Barthlott et al. 2014). Based on the observation, Bulbophyllum and Dendrobium had no difference in seed shape. The seeds of all investigated species were fusiform and did not exhibit great variations (Figures 2A-6A). This seed shape is also known as scobiform elongate seeds and is common to Bulbophyllum and Dendrobium (Barthlott et al. 2014). Most studies showed that seed shape could not be applied for the delimitation of different genera, because fusiform seeds are mostly found in all the subfamilies (Verma et al. 2014).

There was no difference in the location of the embryo inside the seed between Bulbophyllum and Dendrobium observed. All embryos were located in the center of the long axis (Table 1; Figures 2A, 3A, 4A, and 6A), except for $D$. bicaudatum that had a small embryo directed to the micropylar pole (Figure 5A). Dendrobium bifalce had a large embryo occupying a major part of the seed and located at the center of the long axis (Figure 6A). It was also similar to D. tosons, D. purpureum, D. nindii, and D. affine that is native to Indonesia (Hariyanto et al. 2020). Bulbophyllum graveolens and B. phalaenopsis had a wide opening of suspensor of the seed (Figures 2C and 4C, brown arrow), while suspensor opening in B. macranthum was small (Figure 3C, yellow arrow). This opening suspensor is used for allowing the entry of water and fungal hyphae that are required for germination (Arditti and Ghani 2000).

All species observed had smooth testa cell walls and the periclinal walls had no ridges (Table 1). According to
Hariyanto et al. (2020), some species of Dendrobium native to Indonesia presented similar results that testa cell walls of all Dendrobium examined were smooth. In this study, the testa cell walls of all species were covered with smooth and thin cottony-white substances, resulting in a dull velvety appearance of the seeds. This verrucosity is much common in the subfamily Epidendroideae, predominantly in the subtribe Dendrobiinae (Barthlott et al. 2014). In addition, B. phalaenopsis has filament cottony-white substances at the center part (Figure 4D, red arrow). Meanwhile, in $D$. bifalce, there were prominent ridges of the anticlinal walls (Figure 6D, red arrow). The verrucosity shows the presence of waxes (Table 1) in epiphytic taxa, related to their adaptation as epiphytes, and also creates a hydrophobic surface as embryo protection (Gamarra et al. 2018).

Bulbophyllum seeds can be differentiated from seeds of Dendrobium in terms of the orientation of testa cells. All Bulbophyllum observed was spirally oriented. Meanwhile, all Dendrobium was longitudinally oriented and parallel to the long axis (Table 1). Twisted medial cells in Bulbophyllum were revealed by Swamy et al. (2004) and Gamarra et al. (2018) that B. falcatum and B. mysorense also had this type of testa cells. Furthermore, the observation made on $B$. graveolens showed that medial cells apart from being elongated also had a deep groove (Figure 2D, blue arrow) and rounded at the ends (Figure 2D, red arrow). Twisted cells of B. macranthum looked like a rope and more twisted at the micropylar pole (Figures $3 \mathrm{~B}$, C, E) and B. phalaenopsis was strongly twisted with the irregular shape of testa cells at the micropylar pole (Figures 4B, C, E).

Table 1. Main micromorphological characters in Bulbophyllum and Dendrobium seeds

\begin{tabular}{|c|c|c|c|c|c|c|c|c|}
\hline Species & $\begin{array}{c}\text { Seed } \\
\text { shape }\end{array}$ & $\begin{array}{l}\text { Location of } \\
\text { embryo }\end{array}$ & $\begin{array}{c}\text { Ornamentation } \\
\text { of the periclinal } \\
\text { wall } \\
\end{array}$ & Waxes & $\begin{array}{c}\text { Orientation } \\
\text { testa cells }\end{array}$ & $\begin{array}{c}\text { Testa cell } \\
\text { shape } \\
\text { differences* }\end{array}$ & $\begin{array}{c}\text { Testa cell } \\
\text { shape of } \\
\text { medial part }\end{array}$ & $\begin{array}{l}\text { Anticlinal } \\
\text { wall }\end{array}$ \\
\hline \multicolumn{9}{|l|}{ Bulbophyllum } \\
\hline B. graveolens & Fusiform & $\begin{array}{l}\text { Center of the } \\
\text { long axis }\end{array}$ & Smooth & Present & $\begin{array}{l}\text { Spirally } \\
\text { oriented }\end{array}$ & Absent & Elongated & $\begin{array}{l}\text { Raised and } \\
\text { thickened }\end{array}$ \\
\hline B. macranthum & Fusiform & $\begin{array}{l}\text { Center of the } \\
\text { long axis }\end{array}$ & Smooth & Present & $\begin{array}{l}\text { Spirally } \\
\text { oriented }\end{array}$ & Absent & Elongated & $\begin{array}{l}\text { Elevated and } \\
\text { arch-like }\end{array}$ \\
\hline B. phalaenopsis & Fusiform & $\begin{array}{l}\text { Center of the } \\
\text { long axis }\end{array}$ & Smooth & Present & $\begin{array}{l}\text { Spirally } \\
\text { oriented }\end{array}$ & Absent & Elongated & $\begin{array}{l}\text { Raised and } \\
\text { thickened }\end{array}$ \\
\hline \multicolumn{9}{|l|}{ Dendrobium } \\
\hline D. bicaudatum & Fusiform & $\begin{array}{l}\text { Directed to } \\
\text { micropylar } \\
\text { pole }\end{array}$ & Smooth & Present & Parallel & Present & Rectangular & $\begin{array}{l}\text { Raised and } \\
\text { thickened }\end{array}$ \\
\hline D. bifalce & Fusiform & $\begin{array}{l}\text { Center of the } \\
\text { long axis }\end{array}$ & Smooth & Present & Parallel & Absent & Elongated & $\begin{array}{l}\text { Raised and } \\
\text { thickened }\end{array}$ \\
\hline
\end{tabular}

Note: *Testa cell shape differences between chalazal, micropylar, and medial part 

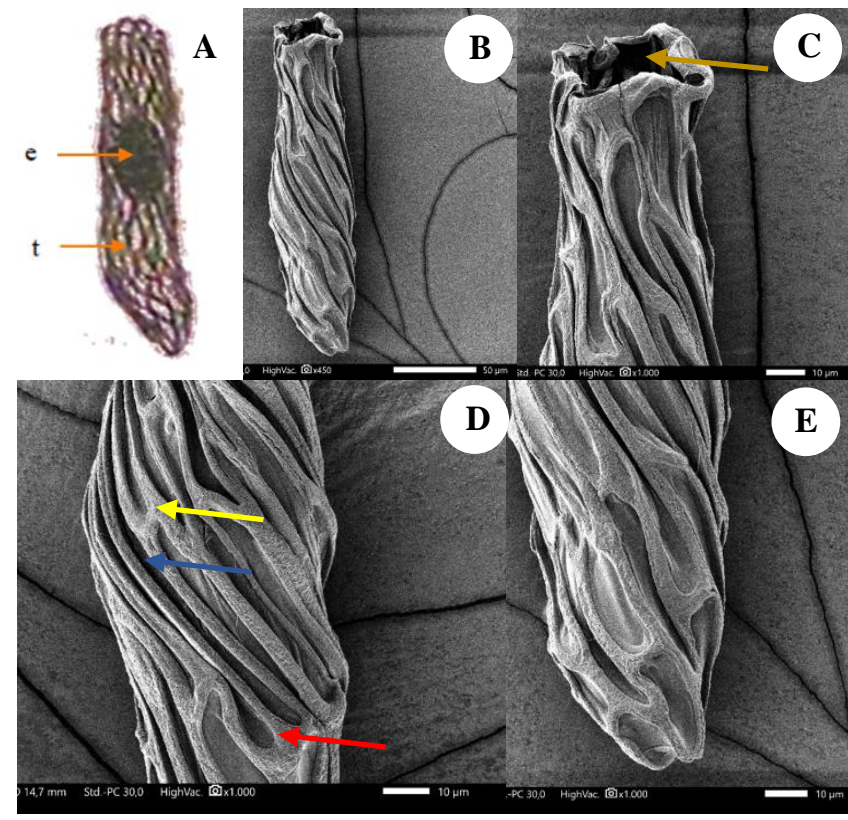

Figure 2. LM and SEM photographs of Bulbophyllum graveolens. A. a seed under LM (e: embryo, t: testa), B. a seed under SEM, C. cells of the chalazal pole (brown arrow indicates the opening of suspensor), D. pattern of testa cells of the medial, (blue arrow indicates deep groove of periclinal testa cell walls; red arrow shows rounded testa cell at the ends; yellow arrow indicates testa cell corners is raised and thickened), E. cells of the micropylar pole. Scale bars: B: $50 \mu \mathrm{m}$ and C-E: $10 \mu \mathrm{m}$

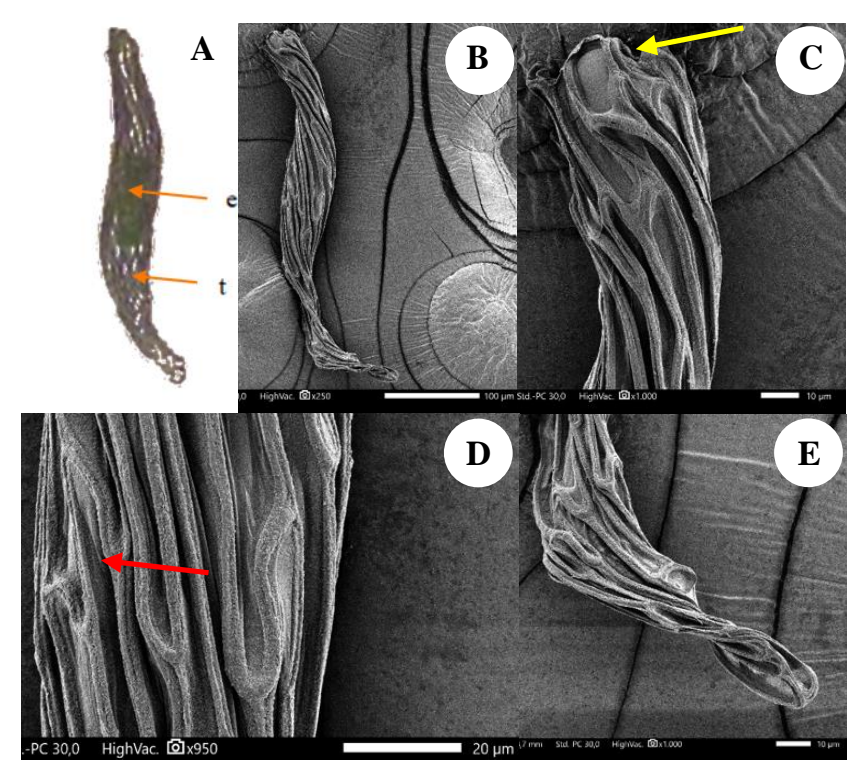

Figure 3. LM and SEM Photographs of Bulbophyllum macranthum. A. a seed under LM (e: embryo, t: testa), B: a seed under SEM, C. cells of the chalazal pole (yellow arrow indicates the opening of suspensor), D. pattern of testa cells of the medial (red arrow indicates the elevated and arch-like anticlinal walls), E. cells of the micropylar pole. Scale bars: B: $100 \mu \mathrm{m}, \mathrm{C}$ and E: 10 $\mu \mathrm{m}, \mathrm{D}: 20 \mu \mathrm{m}$

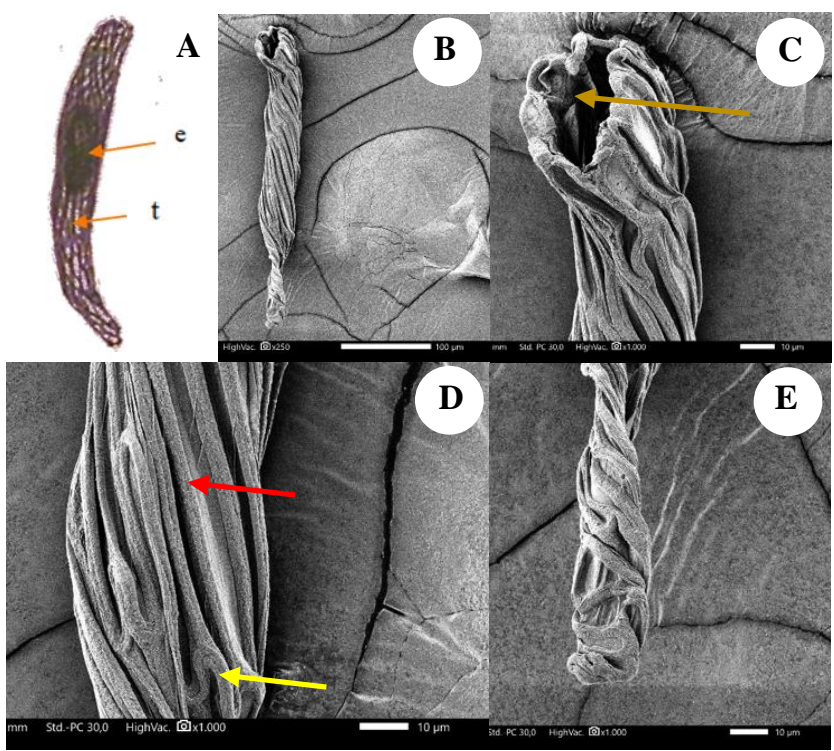

Figure 4. LM and SEM Photographs of Bulbophyllum phalaenopsis. A. a seed under LM (e: embryo, t: testa), B. a seed under SEM, C. cells of the chalazal pole (brown arrow indicates the opening of suspensor), D. pattern of testa cells of the medial (red arrow indicates filament cottony white substance; yellow arrow indicates anticlinal cell walls raised to form a bulge at meeting points between two ends), E. cells of the micropylar pole. Scale bars: B: $100 \mu \mathrm{m}$ and C-E: $10 \mu \mathrm{m}$

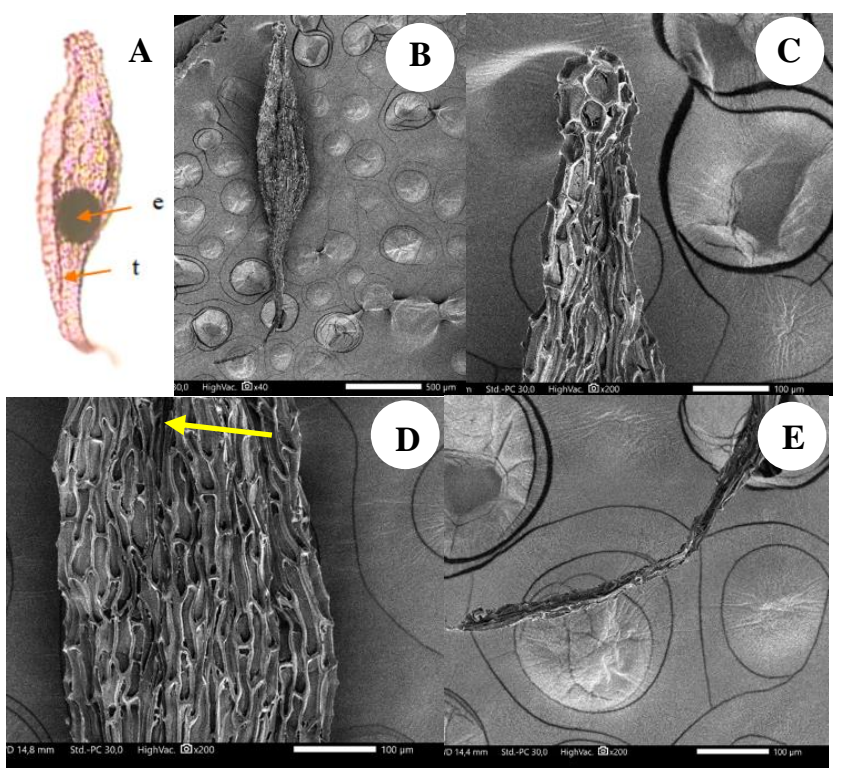

Figure 5. LM and SEM Photographs of Dendrobium bicaudatum. A. a seed under LM $(e=$ embryo, $t=$ testa $), B$. a seed under SEM, C. cells of the chalazal pole, D. pattern of testa cells of the medial (yellow arrow indicates longitudinally deep groove), E. cells of the micropylar pole. Scale bars: B: $500 \mu \mathrm{m}$ and C-E: $100 \mu \mathrm{m}$. 


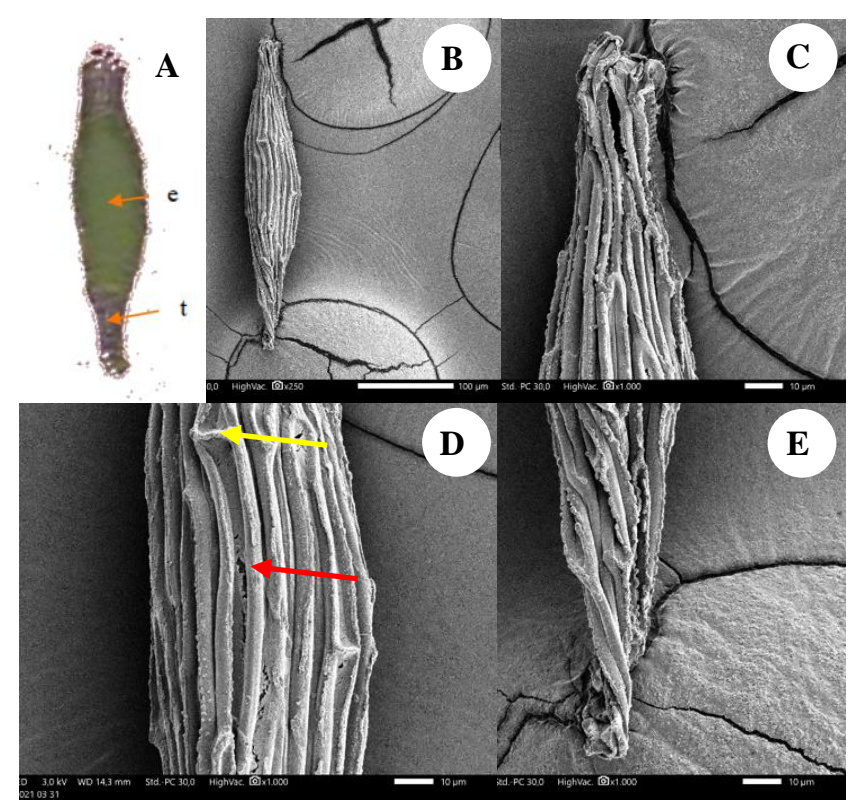

Figure 6. LM and SEM Photographs of Dendrobium bifalce. A. a seed under LM (e: embryo, t: testa), B. a seed under SEM, C. cells of the chalazal pole, D. pattern of testa cells of the medial (yellow arrow indicates anticlinal cell walls raised to form a bulge at the meeting points between two ends; red arrow indicates prominent ridges of the anticlinal walls), E. cells of the micropylar pole. Scale bars: B: $100 \mu \mathrm{m}$ and C-E: $10 \mu \mathrm{m}$

Testa cell shape differences between chalazal, micropylar, and medial parts existed only in D. bicaudatum (Table 1). Our examination results showed that the testa cell shape in the medial part was elongated in all species, except for $D$. bicaudatum that had irregular shapes with a smaller size than other species. This species also had a polygonal shape of testa cells in the chalazal pole (Figure 5C) and from the medial part to the chalazal pole, there was a deep groove along the axis (Figure 5D, yellow arrow). Cells at the micropylar pole had an appendage at the end with irregular forms (Figure 5E). A similar result was obtained by Hariyanto et al. (2020) that D. leporinum also had this polygonal shape of testa walls in the chalazal pole.

The anticlinal walls of testa cells of Bulbophyllum and Dendrobium were raised and thickened (Table 1). This result is similar to the research conducted by Chaudhary et al. (2014) on Dendrobium spp. which was collected from eastern North India. All of the seeds showed thickening of testa cell walls and thus giving important information that anticlinal cell walls were well developed and strongly raised in Dendrobium. In B. phalaenopsis and D. bifalce, these walls were raised to form a bulge at the meeting points between two ends (Figures 4D and 6D, yellow arrow). Bulbophyllum macranthum had anticlinal walls that elevated and arch-like (Figure 3D, red arrow). Barthlott et al. (2014) has also mentioned that many species within subfamily Epidendroideae have this character. The seeds that have these elevated anticline walls will fall more slowly, so they can better attach to the substrate (Barthlott et al. 2014; Gamarra et al. 2018). Furthermore, Vij et al. (1992) described that the thickening testa wall provided rigidity to the seed coat and protected the embryo, and the hygroscopic nature of seed provided metabolic activities during germination.

\section{Seed size, seed volume, and seed air space}

The seeds size of the Bulbophyllum and Dendrobium studied varies greatly and there were no differences between seed length (SL) and seed width (SW). The SL ranged between $0.28 \pm 0.035 \mathrm{~mm}$ to $1.1 \pm 0.082 \mathrm{~mm}$ and $\mathrm{SW}$ ranged between $0.067 \pm 0.009$ to $0.337 \pm 0.048 \mathrm{~mm}$ (Table 2). Barthlott et al. (2014) used the length of the seed for grouping the seed size and there are five categories of seeds, i.e. very small $(0.1-0.2 \mathrm{~mm})$, small $(0.2-0.5 \mathrm{~mm})$, medium $(0.5-0.9 \mathrm{~mm})$, large $(0.9-2.0 \mathrm{~mm})$, and very large (2.0-6.0 mm). Based on this classification, the seeds of $D$. bicaudatum were classified as large seeds (1.100 \pm 0.082 $\mathrm{mm})$ and the others as small seeds. Bulbophyllum mysorense from India had a shorter SL $(0.174 \pm 0.014 \mathrm{~mm})$ than all of the Bulbophyllum taxa observed in this research but had the same average of SW $(0.073 \pm 0.009 \mathrm{~mm})$ (Swamy et al. 2004). Dendrobium bifalce in this research has a similar length with $D$. purpureum $(0.353 \pm 0.0019$ $\mathrm{mm}$ ) (Hariyanto et al. 2020).

The maximum SL/SW ratio of the seeds was observed in B. phalaenopsis $(6.375 \pm 0.797)$, while D. bicaudatum had the minimum value $(3.294 \pm 0.389)$ (Table 2$)$. This $\mathrm{SL} / \mathrm{SW}$ ratio provides the data of the relative degree of truncation of the orchid seeds (Verma et al. 2014). The value of SL/SW between Bulbophyllum and Dendrobium was not different significantly, except for $B$. macranthum and the species that had truncated seed $(\mathrm{SL} / \mathrm{SW}<6)$ were B. graveolens, B. macranthum, D. bicaudatum, and D. bifalce. Meanwhile, only B. phalaenopsis had elongated seeds $(\mathrm{SL} / \mathrm{SW}>6)$. Previous studies showed that higher seed volume was the result of an increase in SL and SW of the seeds and embryos (Vij et al. 1992; Arditti and Ghani 2000; Swamy et al. 2004; Verma et al. 2014). This statement is congruent with the result of this study, there was a positive correlation between the size of the seed and $\mathrm{SV}$, and D. bicaudatum has the biggest value of seed volume (SV) $(33.400 \pm 10.0 \mathrm{~mm} 3 \times 10-3)$.

The length of the embryo (EL) of the investigated species varies between $0.067 \pm 0.005 \mathrm{~mm}$ (B. graveolens) and $0.250 \pm 0.00 \mathrm{~mm}(D$. bicaudatum $)$ and widths of the embryos (EW) between $0.052 \pm 0.009$ (B. phalaenopsis) and $0.200 \pm 0.00$ (D. bicaudatum) (Table 3). Based on the results, EL and EW of Dendrobium species are bigger than Bulbophyllum (Table 3). Larger embryos give more benefit to epiphytic species since they will increase the success of germination and seedling establishment because they can deposit more nutrients and are beneficial to adapt in poor environments (Chaudhary et al. 2014). The large embryo have a bigger chance of being survived and establishment success (Zhang et al. 2015; Calevo et al. 2017). The shape of embryos of B. graveolens, B. macranthum and $D$. bicaudatum were not different significantly and seemed to be spherical with a low EL/EW value (1.083 \pm 0.096 to $1.756 \pm 0.218$ ) (Table 3). Bulbophyllum phalaenopsis and $D$. bifalce had high EL/EW values, representing that the embryos are more elliptical rather than spherical (Güler 2016). 
Table 2. Micromorphometric data of Bulbophyllum and Dendrobium seeds

\begin{tabular}{lcccc}
\hline \multicolumn{1}{c}{ Species } & SL $(\mathbf{m m})$ & SW $(\mathbf{m m})$ & SL/SW $(\mathbf{m m})$ & SV $(\mathbf{m m 3 \times 1 0 - 3})$ \\
\hline Bulbophyllum & & & & \\
B. graveolens & $0.280 \pm 0.035$ & $0.072 \pm 0.005$ & $3.888 \pm 0.66$ & $0.383 \pm 0.044$ \\
B. macranthum & $0.395 \pm 0.288$ & $0.070 \pm 0.014$ & $5.827 \pm 1.31$ & $0.517 \pm 0.209$ \\
B. phalaenopsis & $0.425 \pm 0.019$ & $0.067 \pm 0.009$ & $6.375 \pm 0.797$ & $0.516 \pm 0.16$ \\
Dendrobium & & & & \\
D. bicaudatum & $1.100 \pm 0.082$ & $0.337 \pm 0.048$ & $3.294 \pm 0.389$ & $33.400 \pm 10.0$ \\
D. bifalce & $0.337 \pm 0.033$ & $0.075 \pm 0.006$ & $4.522 \pm 0.608$ & $0.498 \pm 0.083$ \\
\hline
\end{tabular}

Note: SL: Seed length, SW: Seed width, SV: Seed volume

Table 3. Micromorphometric data of Bulbophyllum and Dendrobium embryos

\begin{tabular}{lcccccc}
\hline \multicolumn{1}{c}{ Species } & $\begin{array}{c}\text { EL } \\
(\mathbf{m m})\end{array}$ & $\begin{array}{c}\text { EW } \\
(\mathbf{m m})\end{array}$ & $\begin{array}{c}\text { EL/EW } \\
(\mathbf{m m})\end{array}$ & $\begin{array}{c}\text { EV } \\
(\mathbf{m m 3 x 1 0 - 3})\end{array}$ & $\begin{array}{c}\text { SV/EV } \\
(\mathbf{m m 3 \times 1 0 - 3})\end{array}$ & $\begin{array}{c}\text { SAS } \\
(\boldsymbol{\%})\end{array}$ \\
\hline Bulbophyllum & & & & & & \\
B. graveolens & $0.067 \pm 0.005$ & $0.062 \pm 0.005$ & $1.083 \pm 0.096$ & $0.139 \pm 0.0283$ & $2.879 \pm 0.802$ & $62.64 \pm 12.79$ \\
B. macranthum & $0.117 \pm 0.012$ & $0.067 \pm 0.009$ & $1.756 \pm 0.218$ & $0.287 \pm 0.0979$ & $1.808 \pm 0.304$ & $43.33 \pm 10.82$ \\
B. phalaenopsis & $0.140 \pm 0.011$ & $0.052 \pm 0.009$ & $2.712 \pm 0.361$ & $0.211 \pm 0.086$ & $2.602 \pm 0.645$ & $59.81 \pm 9.70$ \\
Dendrobium & & & & & \\
D. bicaudatum & $0.250 \pm 0.00$ & $0.200 \pm 0.00$ & $1.250 \pm 0.00 \mathrm{~b}$ & $5.233 \pm 0.00$ & $6.40 \pm 2.03$ & $83.15 \pm 5.18$ \\
D. bifalce & $0.187 \pm 0.043$ & $0.075 \pm 0.005$ & $2.522 \pm 0.701$ & $0.549 \pm 0.114$ & $0.901 \pm 0.125$ & $10.12 \pm 26.88$ \\
\hline
\end{tabular}

Note: EL: Embryo length, EW: Embryo width, EV: Embryo volume, SAS: Seed air space

Dangat and Gurav (2016) stated that the increase of embryo volume (EV) results in increasing seed weight, thus improving the ability of the seed to float on air and the distribution of the species (Arditti and Ghani 2000). In the end, EV will directly affect the percentage of available air space inside the seed (Verma et al. 2014). In addition to having the largest SV, D. bicaudatum also had the largest volume of EV (5.233 $\mathrm{mm} 3 \times 10-3)$. This value shows that the species has a bigger seed weight. Seeds with a higher ratio of SV/EV are expected to be more buoyant because they have high air space inside the seed (SAS) (Dangat and Gurav 2016). This statement is congruent with our finding that $D$. bicaudatum has the highest $\mathrm{SV} / \mathrm{EV}$ ratio $(6.40 \pm 2.03$ $\mathrm{mm} 3 \times 10-3)$ among others and indeed it has the largest SAS (Table 3).

\section{Seed air space in relation to dispersal area of the species}

The seed air space (SAS) plays a key role in the distribution of orchid species and the large SAS is beneficial in increasing the dispersal area (Arditti and Ghani 2000). Our study result showed that D. bicaudatum had the largest value of SAS $(83.15 \pm 5.18 \%)$ and $D$. bifalce had the smallest value of SAS $(10.12 \pm 26.88 \%)$. Among the taxa observed, the SAS value of Bulbophyllum ranged from $43.33 \pm 10.82 \%$ to $62.64 \pm 12.79 \%$ (Table 3 ). According to O'Byrne (2001), D. bicaudatum had a limited area of distribution (Moluccas, Sulawesi, and the Philippines) (Figure 7, white line). This finding contradicts the statement that the species with higher SAS will have a wide geographic area because the seeds will float in the air longer (Swamy et al. 2004; Hariyanto et al. 2020). The
SAS value above $50 \%$ indicates the seed of the species is light and buoyant, so it can be easily dispersed by wind and spread to a larger occupied area (Hariyanto et al. 2020). The study conducted by Tongbram et al. (2012) on some orchids such as (Aerides odorata Lour., Ascocentrum himalaicum (Deb, Sengupta \& Malick) Aver., Cymbidium iridioides D. Don, Dendrobium crepidatum Lindl. \& Paxton, Hygrochilus parishii (Rchb.f.) Pfitzer, Paphiopedilum hirsutissimum (Lindl. ex Hook.) Stein, Papilionanthe vandarum (Rchb.f.), Rhynchostylis retusa (L.) Blume, Taeniophyllum glandulosum Blume, and Vanda coerulea Griff. ex Lindl.) from Manipur, India also gave the same result. Seed air space of $C$. iridioides was the largest among the investigated taxa $(90.5 \%)$, but the species has a limited distribution area than the others with lower air space. This situation is related to the condition during dispersion that the seeds of both species $(C$. irioides and $D$. bicaudatum) did not get the suitable environment to germinate or, in other words, these species have the narrow amplitude of environmental conditions and a highly specific habitat (Tongbram et al. 2012; Verma et al. 2014). Moreover, the existence of orchid seeds depends on the availability of mycorrhizal fungi to obtain the nutrients to germinate naturally. Also, larger air spaces in the orchid seed would affect the turbulence because the seed will float longer in the air. Thus, increased air space may increase floatation time during dispersal event and reduce the average travel distance of the seed. This is reasonable, since the seeds have limited of viability. Most seeds perhaps have lost their viabilities just before reaching a suitable environment (Arditti and Ghani 2000). 


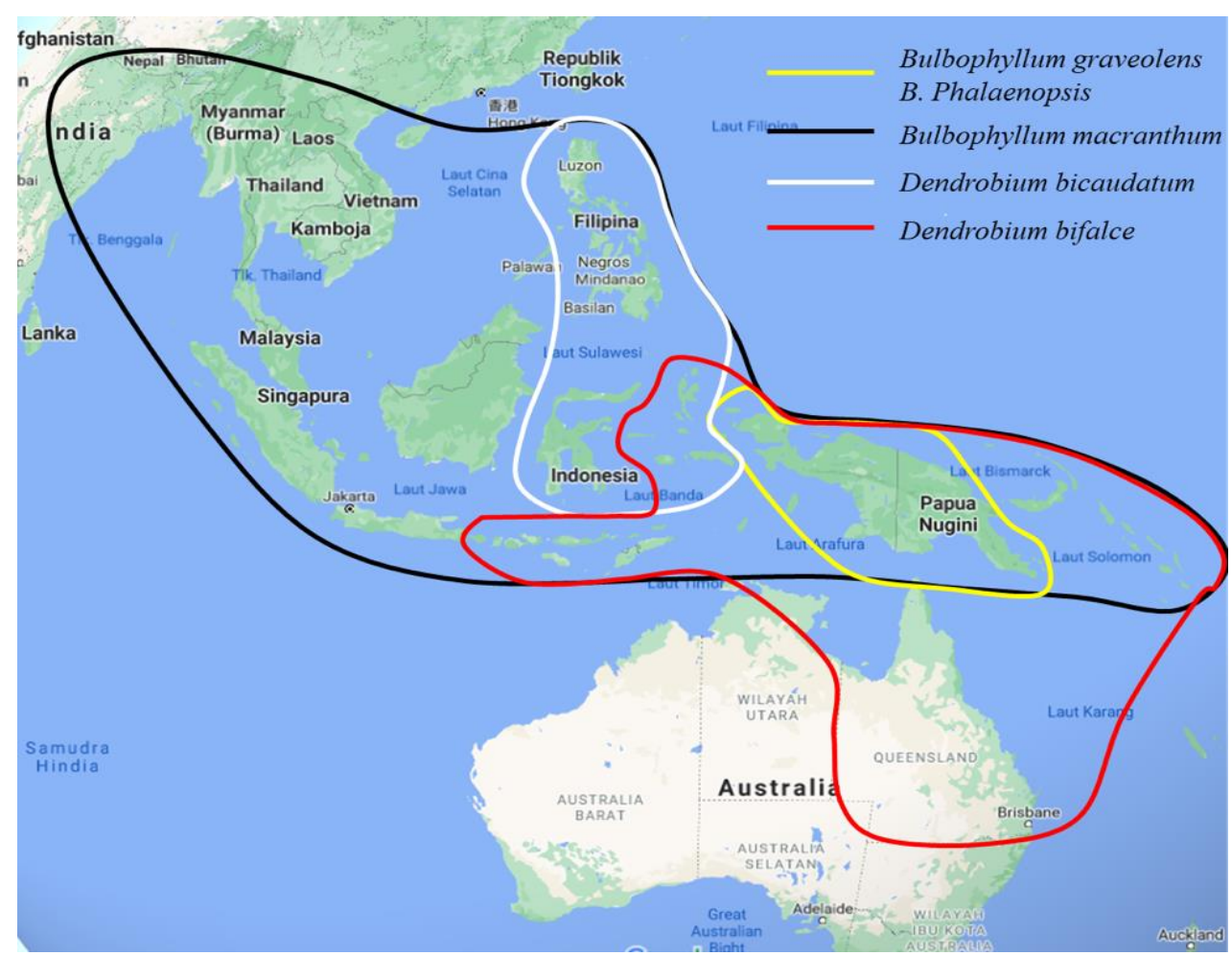

Figure 7. The distribution area of investigated taxa

Bulbophyllum macranthum has a smaller SAS value $(43.33 \pm 10.82 \%)$ than the other taxa, then it can be predicted that the species are distributed in a limited area. In fact, $B$. macranthum was dispersed to a larger area than other species. Based on Vermeulen (1991), it is distributed from Assam, Burma, Vietnam, Thailand, Malaysia, Sumatra, Java, Borneo, Sulawesi, Papua New Guinea, Philippines, reaching Solomon Island (Figure 7, black line). Howe and Smallwood (1982) assumed that the dispersal mechanism for the species with small SAS like B. macranthum is by water (hydrochory) along the coast. Moreover, Diantina et al. (2020) stated that the testa covered by waxes could be a very useful character for seed distribution along the coastal stream. This hypothesis also applies to $D$. bifalce that has the smallest air space (10.12 \pm 26.88$)$ (Table 3) and distributes in the Lesser Sunda Islands, Moluccas, New Guinea, and Queensland to Solomon Islands (Figure 7, red line) (O’Byrne 1994).

The SAS values between $B$. graveolens and $B$. phalaenopsis were not different significantly. Both of them have SAS ranging from $59.81 \pm 9.70 \%$ to $62.64 \pm 12.79 \%$. Those values were bigger than $D$. bifalce, then it can be analyzed that the distribution area is larger. On the contrary, based on O'Byrne (1994), B. graveolens and B. phalaenopsis are native to Papua New Guinea (Figure 7, yellow line). Bulbophyllum graveolens was reported found in scattered locations. This species is uncommon and usually found only in isolated stands, growing on tree trunks of the lower and middle layers of the forest (O'Byrne 1994). The reason for this condition is that they have a very specific environment (habitat and substrate) and mycorrhiza requirements for seed germination (Arditti and Ghani 2000; Tongbram et al. 2012; Ramudu et al. 2020). Zhang et al. (2018) stated that orchids display various levels of specificity to their fungal hosts, then it can be seen clearly that the environment with low fungal diversity would restrict the orchids to only certain habitats where these specific fungi appear. There would be heavy mortality at any stage of seedling development and very few seed seedlings will grow successfully and give a rise to mature plants (Ramudu et al. 2020).

In conclusion, all seeds of the orchid species examined have the same shape and similar testa walls condition with verrucosity as one of the key characteristics of epiphytes. The difference between Bulbophyllum and Dendrobium observed is in the orientation of testa walls. There are no large variations in the quantitative characters of those two genera, including the SAS value. The dispersal mechanism and distribution area of the orchid species can be predicted by their SAS values. However, the values are not always positively correlated with the distribution area of the species. Even SAS value is large enough. Other factors inhibit the spread of the species, such as the absence of specific mycorrhiza. The seed with small SAS tends to be dispersed by water.

\section{ACKNOWLEDGEMENTS}

We would like to thank Research Center for Plant Conservation and Botanic Gardens- The National Research and Innovation Agency for providing the funding In House 
Research Programme. The authors also acknowledge the facilities, scientific and technical support from Zoology Characterization Laboratories, The National Research and Innovation Agency through E-Layanan Sains, Badan Riset dan Inovasi Nasional. All of the authors are main contributors and gave the same proportion of the research and publication process.

\section{REFERENCES}

Arditti J, Ghani AKA. 2000. Numerical and physical properties of orchid seeds and their biological implications. New Phytol 145: 367-421. DOI: 10.1046/j.1469-8137.2000.00587.x.

Barman D, Devadas R. 2013. Climate change on orchid population and conservation strategies: A review. J Crop Weed 9 (2): 1-12.

Barthlott W, Große-Veldmann B, Korotkova N. 2014. Orchid seed diversity: A scanning electron microscopy survey. Englera 32: 239.

Calevo J, Giovanni A, Cornara L, Peccenini S, Monroy F. 2017. Orchis patens Desf.: Seed morphology of an endangered Mediterranean orchid. Plant Biosyst 151 (5): 770-774.

Chaudhary B, Chattopadhyay P, Banerjee N. 2014. Modulations in seed micromorphology reveal signature of adaptive species-diversification in Dendrobium (Orchidaceae). J Ecol 4 (2): 33-42. DOI: 10.4236/oje.2014.42005.

Comber JB. 2001. Orchids of Sumatra. The Royal Botanic Gardens, Kew, UK.

Dangat BT, Gurav RV. 2016. Studies on seed morphometry of Habenaria species from Western Ghats, India. Richardiana XVI: 174-188.

Diantina S, McGill C, Millner J, Nadarajan J, Prithcard HW, McCormick AC. 2020. Comparative seed morphology of tropical and temperate orchid species with different growth habits. Plants 9 (161): 1-11.

Gamarra R, Ortúñez, Cela PG, Merencio A. 2018. Seed micromorphology of Orchidaceae in the Gulf of Guinea (West Tropical Africa). Plant Syst Evol 304: 665-677. DOI: 10.1007/sO0606-018-1497-0.

Güler N. 2016. Seed micromorphology of Orchis Tourn. ex L. (Orchidaceae) and allied genera growing in Edirne province, Turkey. Phyto Keys 68: 9-25. DOI: 10.3897/phyto keys.68.8746.

Hariyanto S. 2019. Variations in seed micromorphology and morphometry of native Indonesian Phalaenopsis and Paphiopedilum orchids. Biodiversitas 20 (12): 3559-3567. DOI: 10.13057/biodiv/d201214.

Hariyanto S, Pratiwi IA, Utami ESW. 2020. Seed morphometry of native Indonesian orchids in the genus Dendrobium. Scientifica 2020 3986369. DOI: $10.1155 / 2020 / 3986369$.

Howe HF, Smallwood J. 1982. Ecology of seed dispersal. Ann Rev Ecol Syst 13: 201-228.
Koene FM, Amano É, Smidt EdC, Ribas LLF. 2020. Asymbiotic germination and morphological studies of seeds of Atlantic Rainforest micro-orchids (Pleurothallidinae). PLoS One 15 (12): e0243297. DOI: 10.1371/journal.pone.0243297.

O'Byrne P. 1994. Lowland Orchids of Papua New Guinea. SNP Publishers, Singapore.

O'Byrne P. 2001. A to Z of South East Asian Orchid Species Vol 1. Orchid Society of South East Asia, Singapore.

Ramudu J, Khasim SM. 2015. Seed morphometry of some Indian orchids with special reference to their inter-relationships and ecological significance. J Orchid Soc India 29: 47-53.

Ramudu J, Khasim SM, Ramesh G. 2020. Orchid Biology: Recent Trends and Challenge. In: Khasim SM, Hedge SN, González-Arnao MT, Thammasiri K (eds.). Orchid Seed Ultrastructure: Ecological and Taxonomic Implications with Reference to Epidendroideae (Orchidaceae). Springer Nature, Singapore. DOI: 10/1007/978-98132-9456-1.

Şeker ŞS, Akbulut MK, Şenel G. 2021. Seed morphometry and ultrastructure studies on some Turkish orchids (Orchidaceae). Microsc Res Tech 2021: 1-12. DOI: 10.1002/jemt.23796.

Swamy KK, Kumar HNK, Ramakhrisna TM, Ramaswamy SN. 2004. Studies on seed morphometry of epiphytic orchids from Western Ghats of Karnataka. Taiwania 49 (2): 124-140. DOI: 10.6165/tai.2004.49 (2).124.

Tongbram J, Rao AN, Vij SP. 2012. Seed morphometric studies in some orchids from Manipur. J Orchid Soc India 26 (1-2): 25-29.

Verma J, Sharma K, Thakur K, Sembi JK, Vij SP. 2014. Study on seed morphometry of some threatened Western Himalayan orchids. Turk J Bot 38: 234-251. DOI: 10.3906/bot-1307-14.

Vermeulen JJ. 1991. Orchids of Borneo Volume 2: Bulbophyllum. Bentham-Moxon Trust, Richmond, UK.

Vermeulen JJ, O’Byrne P, Lamb A. 2015. Bulbophyllum of Borneo. Natural History Publications (Borneo), Kinabalu, Malaysia.

Vij SP, Kaur P, Kaur S, Kaushal PS.1992. The orchid seeds: Taxonomic, evolutionary and functional aspects. J Orchid Soc India 6: 91-107.

Wood JJ. 2013. A guide to Dendrobium of Borneo. Natural History Publications (Borneo), Kinabalu, Malaysia.

Yeung EC. 2017. A perspective on orchid seed and protocorm development. Bot Stu 58: 1-14. DOI: 10.1186/s40529-016-0155-5.

Zhang FP, Zhang JJ, Yan N, Hu H, Zhang SB. 2015. Variations in seed micromorphology of Paphiopedilum and Cypripedium (Cypripedioideae), Orchidaceae). Seed Sci Res 2015: 1-7. DOI: 10.1017/S0960258515000276.

Zhang S, Yang Y, Li J, Qin J, Zhang W, Huang W, Hu H. 2018. Physiological diversity of orchids. Plant Divers 40: 196-208. DOI: 10.1016/ j.pld.2018.06.003. 